\title{
A Case of Altered Mental Status and Acute Renal Failure Due to Tramadol and Alprazolam Usage
}

Tramadol ve Alprazolam Kullanımına Bağlı Bilinç Değişikliği ve Böbrek Yetmezliği

Burak Subaşı

Psychiatry Unit, Elazığ Education and Research Hospital, Elazığ, Turkey

\section{ABSTRACT}

Introduction: Tramadol, as a centrally acting synthetic analgesic agent, shows its effects by multiple transmitter systems. Tramadol usage may cause respiratory depression, seizures, renal failure. Alprazolam is a triazolobenzodiazepin derivative agent that has anxiolytic and antidepressant effects. High dose usage can cause side effects such as light-headedness, drowsiness, respiratory depression, delirium, coma, and death.

Case Report: In this case report, we represent a 58-year-old male patient admitted to Emergency Department with altered mental status and acute renal failure after co-ingestion of tramadol and alprazolam. With supportive mechanical ventilation and hemodialysis he was discharged with fully remission on the ninth day of follow-up.

Conclusion: Clinicians should be aware of cases presented with altered mental status and kidney failure associated with tramadol and alprazolam usage.

Keywords: Tramadol, alprazolam, altered mental status, renal failure

Received: 18.03.2013 Accepted: 25.03.2013

\section{ÖZET}

Giriş: Tramadol santral etkili sentetik analjezik bir ajan olup; çoklu transmitter sistemleri üzerinden etkilerini göstermektedir. Tramadol kullanımı solunum depresyonu, nöbet, böbrek yetmezliği gibi durumlara neden olabilir. Alprazolam ise triazolobenzodiazepin türevi anksiyolitik ve antidepresif etkili bir ajandır. Yüksek dozlarda alprazolam kullanımı sersemlik, uyku hali, solunum depresyonu, deliryum, koma ve ölüm gibi yan etkilere neden olabilir.

Olgu Sunumu: Biz bu vaka sunumunda acil servise tramadol ve alprazolamın birlikte alımı sonrası gelişen bilinç bozukluğu ve akut böbrek yetmezliği olan 58 yaşında bir erkek hasta sunuyoruz. Destekleyici mekanik ventilasyon ve hemodiyaliz tedavisi sonrası durumunda belirgin düzelme olan hasta yatışının dokuzuncu gününde taburcu edildi.

Sonuç: Klinisyenler tramadol ve alprazolam kullanımı olan hastalarda bilinç değişikliği ve böbrek yetmezliği gibi durumların olabileceği konusunda dikkatli olmalıdır.

Anahtar Kelimeler: Tramadol, alprazolam, bilinç bozukluğu, böbrek yetmezliği

Geliş Tarihi: 18.03.2013 Kabul Tarihi: 25.03.2013

\section{Giriş}

Tramadol santral etkili sentetik analjezik bir ajan olup; orta ağır şiddette akut ve kronik ağıının semptomatik tedavisi için kullanılan bir ajandır (1). Alprazolam ise triazolobenzodiazepin türevi anksiyolitik ve antidepresif etkili bir ajan olup; genellikle agorafobi, panik bozukluğu tedavisinde sıkıkla günde 0,75-4 mg arasında bazen 6-9 mg/gün dozlarında kullanılmaktadır (2).

Bu bildiride tramadol ve alprazolamın birlikte kullanımı sonucu gelişen bilinç bozukluğu ve akut böbrek yetmezliği olgusu tartışılmışır. 


\section{Olgu Sunumu}

Ellisekiz yaşında 30 yı önce geçirdiği trafik kazası sonrası sol bacağı diz altından ampüte erkek hasta, ağrıları için 10 yıldır günde 200 mg tramadol kullanıyordu. Beş yıl önce gün içinde bunaltı, daralma, huzursuzluk, uykusuzluk hisleri nedeniyle psikiyatriye başvuran hastaya anksiyete bozukluğu tanısı konmuş tedavi için bir seçici serotonin geri alım inhibitörü olan sitalopram $20 \mathrm{mg} / \mathrm{gün}$ ve uykusuzluk şikâyeti için alprazolam 1 mg/gün reçete edilmişti. Süreç içinde şikâyetleri belirgin oranda düzelen hastanın alprazolam dozu doktor kontrolünde kesilmeye çalışılmış sitalopram 20 mg/gün tedavisine devam etmesi önerilmişti. Bir yıllık tedavinin ardından hastanın aldığı sitalopram kesilmiş ve şikâyetlerinin yinelemediği gözlenen hastaya şikâyeti olması halinde polikliniğe başvurması önerilmişti. Yakınlarından alınan bilgiden hastanın ara ara olan uykusuzluk şikâyetine iyi geldiğini düşünerek alprazolama devam ettiği öğrenildi. Acil servise bilinç bulanıklığı, görsel halüsinasyonlar, idrar yapmada ve solunumda güçlük nedeniyle getirilen hastanın genel durumu kötü olduğu için anestezi yoğun bakımına alındı. Özgeçmişinde koroner arter hastalığı, konjestif kalp yetmezliği, böbrek taşı öyküsü olup; uzun süredir Ramipril 5 mg/gün, Amlodipin 10 mg/gün, İzosorbit 5-mononitrat 60 mg/gün, asetil salisilik asit 100 mg/gün, deksketeprofen 25 mg/gün kullanıyordu. Yapılan muayenede bilinci kapalı, Glasgow koma skoru 3'dü. Tansiyon 110/70, nabız 110/dk, sO \%67 idi. Hastanın ekokardiyografisinde ejeksiyon fraksiyonu \%40-45 olarak ölçüldü. Beyin MRG'sinde diffüz hafif serebral ödem dışında bir patoloji saptanmadı. Akciğerlerinde raller vardı ve solunumu yüzeyeldi. Hastanın solunumu mekanik ventilasyonla desteklendi. Tam kan sayımı, karaciğer fonksiyon testleri normal sınırlarda idi. İzleminin 3. gününde kreatinin değeri $8 \mathrm{mg} / \mathrm{dL}$ olan hasta acilen diyalize alındı. Günaşırı uygulanan diyaliz sonrasında beşinci günde kreatinin değeri 1,6 mg/dL'ye geriledi. Hastanın laboratuvar tetkiklerinin normal olarak bulunması ve genel durumunda düzelme olması üzerine yatışının 9. gününde taburcu edildi. Hasta taburcu edildikten sonra acile getirildiği gün çok ağrısı olduğu ve uyuyamadığı için aynı gün içinde 400 mg tramadol ve 3 mg alprazolam alıp uyuduğunu sonrasını hatırlamadığını belirtiyordu.

\section{Tartışma}

Tramadol santral etkili sentetik analjezik bir ajan olup; orta ağır şiddette akut ve kronik ağrının semptomatik tedavisi için kullanılan bir ajandır (1). Diğer opiat türevlerinin aksine tramadolun $\mu$ opiat reseptörleri üzerine daha az afinite gösterip; GABA A reseptörleri üzerine agonistik ve serotonin ve noradrenalin geri alımı üzerine azaltıcı etkileri mevcuttur $(1,3)$. Tramadol'un sık görülen yan etkileri sersemlik, baş dönmesi olup; nadiren solunum depresyonu ve nöbet yapabildiği bilinmektedir. Genel kullanım şekli ve doz aralığı 50 mg oral, 50-100 mg enjeksiyon yoluyla ve 100 mg rektal yolladır. Toplam günlük doz 400 mg'ı geçmemelidir (4). Literatürde ayrıca tramadol kullanımına bağlı olduğu düşünülen solunum depresyonu ve böbrek yetmezliği gelişen bir olgu mevcuttur (5).

Alprazolam ise triazolobenzodiazepin türevi anksiyolitik ve antidepresif etkili bir ajan olup; genellikle agorafobi, panik bozukluğu tedavisinde sıklıkla günde 0,75-4 mg arasında bazen 6-9 mg/ gün dozlarında kullanılmaktadır (2). Alprazolamın özellikle yüksek dozlarda kullanımıyla sersemlik, uyku hali, solunum depresyonu, yüksek dozlarda deliryum, koma ve ölüm görülebilir (6). Tramadolün tek başına kullanımı ya da alprazomla birlikte kullanımına bağlı olduğu düşünülen ölümle sonuçlanan vaka bildirimleri literatürde mevcuttur $(7,8)$.

Literatüre bakıldığında tramadol kullanımına ve alprazolamın hem kullanımı hem de kesilmesine bağlı deliryum vakaları bildirilmiştir $(6,9,10)$. Ayrıca tek başına tramadolün böbrek yetmezliği etkisi olabileceği, her iki ilacın da santral sinir sistemi, solunum ve kalp fonksiyonları üzerine baskılayıcı etkilerinin olduğu bilinmektedir $(5,6)$. Bu vakada hastamızın aldığı tramadol hidroklorür ve alprazolam gibi çoklu transmitter üzerine etkileri olan ajanların birlikte kullanımının etkilerini artırıcı özellikleri olması, diğer ilaçlarla etkileşiminin net bilinmemesi ve alınan dozların kullanım sınırları içinde olmasıyla birlikte hastamızın yaşının ileri olması, çoklu ilaç kullanımı, ek hastalıklarının oluşu gibi nedenler metabolik dengeyi bozarak böyle bir duruma yol açmış olabilir.

Sonuç olarak bu hastada görülen bilinç bulanıklığı, halüsinasyonlar gibi zihinsel belirtilerin ilaçlar tarafından tetiklendiği, sonrasında olan metabolik bozulmanın da tabloyu devam ettirdiği düşünülebilir. Bu vakayı sunmamızdaki amaç tramadol ve alprazolamın birlikte kullanımında olabilecek böyle bir duruma dikkat çekmektir. Bu etkinin diğer narkotik analjezik ve benzodiazepin grubu ilaçların birlikte kullanımı sonrasında da görülebileceği akılda tutulmalıdır.

Informed Consent: Written informed consent was obtained from patient who participated in this case.

Peer-review: Externally peer-reviewed.

Conflict of Interest: The authors declared no conflict of interest.

Financial Disclosure: The authors declared that this study has received no financial support.

Hasta Onamı: Yazılı hasta onamı bu olguya katılan hastadan alınmıştır.

Hakem Değerlendirmesi: Dış bağımsız.

Çıkar Çatışması: Yazarlar çıkar çatışması bildirmemişlerdir.

Finansal Destek: Yazarlar bu çalışma için finansal destek almadıklarını beyan etmiş̧lerdir.

\section{Kaynaklar}

1. Grond S, Sablotzki A. Clinical pharmacology of tramadol. Clin Pharmacokinet 2004; 43: 879-923. [CrossRef]

2. Schulz M, Schmoldt A. Therapeutic and toxic blood concentrations of more than 500 drugs. Pharmazie 1997; 52: 895-910. 
3. Manocha A, Sharma KK, Mediratta PK. On the mechanism of anticonvulsant effect of tramadol in mice. Pharmacol Biochem Behav 2005; 82: 74-81. [CrossRef]

4. Keskinbora K, Aydınlı I. Atipik Opioid Analjezik: Tramadol. Agri 2006; 18: 5-19.

5. Barnung SK, Treschow M, Borgbjerg FM. Respiratory depression following oral tramadol in a patient with impaired renal function. Pain 1997; 71: 111-2. [CrossRef]

6. Guadreault P, Guay J, Thivierge RL, Verdy L. Benzodiazepine poisoning: Clinical and pharmacologic considerations and treatment. Drug Safety 1991; 6: 297.
7. De Decker K, Cordonnier J, Jacobs W, Coucke V, Schepens P, Jorens PG. Fatal intoxication due to tramadol alone: case report and review of the literature. Forensic Sci Int 2008; 175: 79-82. [CrossRef]

8. Michaud K, Augsburger M, Romain N, Giroud C, Mangin P. Fatal overdose of tramadol and alprazolam. Forensic Sci Int 1999; 105: 185-9. [CrossRef]

9. Agrawal A, Diwan SK, Mahajan R. Severe delirium following single dose of tramadol. Indian J Med Sci 2009; 63: 80-1. [CrossRef]

10. Zalsman G, Hermesh H, Munitz H. Alprazolam withdrawal delirium: a case report. Clin Neuropharmacol 1998; 21: 201-2. 